\title{
Red Mountain Volcano-a Spectacular and Unusual Cinder Cone in Northern Arizona
}

\begin{abstract}
D ed Mountain, located in the Coconino National Forest of northern Arizona, 25 miles northwest of Flagstaff, is a volcanic cinder cone that rises 1,000 feet above the surrounding landscape. It is unusual in having the shape of a " $U$," open to the west, and in lacking the symmetrical shape of most cinder cones. In addition, a large natural amphitheater cuts into the cone's northeast flank. Erosional pillars called "hoodoos" decorate the amphitheater, and many dark mineral crystals erode out of its walls. Studies by U.S. Geological Survey (USGS) and Northern Arizona University scientists suggest that Red Mountain formed in eruptions about 740,000 years ago.
\end{abstract}

Red Mountain is one of several hundred cinder cones within a swath of volcanic landscape that extends 50 miles eastward from Williams, Arizona, through Flagstaff to the canyon of the Little Colorado River. Geologists call this belt of volcanoes the San Francisco Volcanic Field, named for San Francisco Mountain, whose tallest peak is 12,633 feet above sea level, the highest elevation in Arizona. Red Mountain rises about 1,000 feet above the surrounding landscape, and its crest is at 7,965 feet elevation. The San Francisco Volcanic Field has been active for about 6 million years, and Red Mountain is roughly 740,000 years old.

Red Mountain is unusual in that its internal structure is exposed. This is not the case at most cinder cones in the San Francisco Volcanic Field, because erosion has

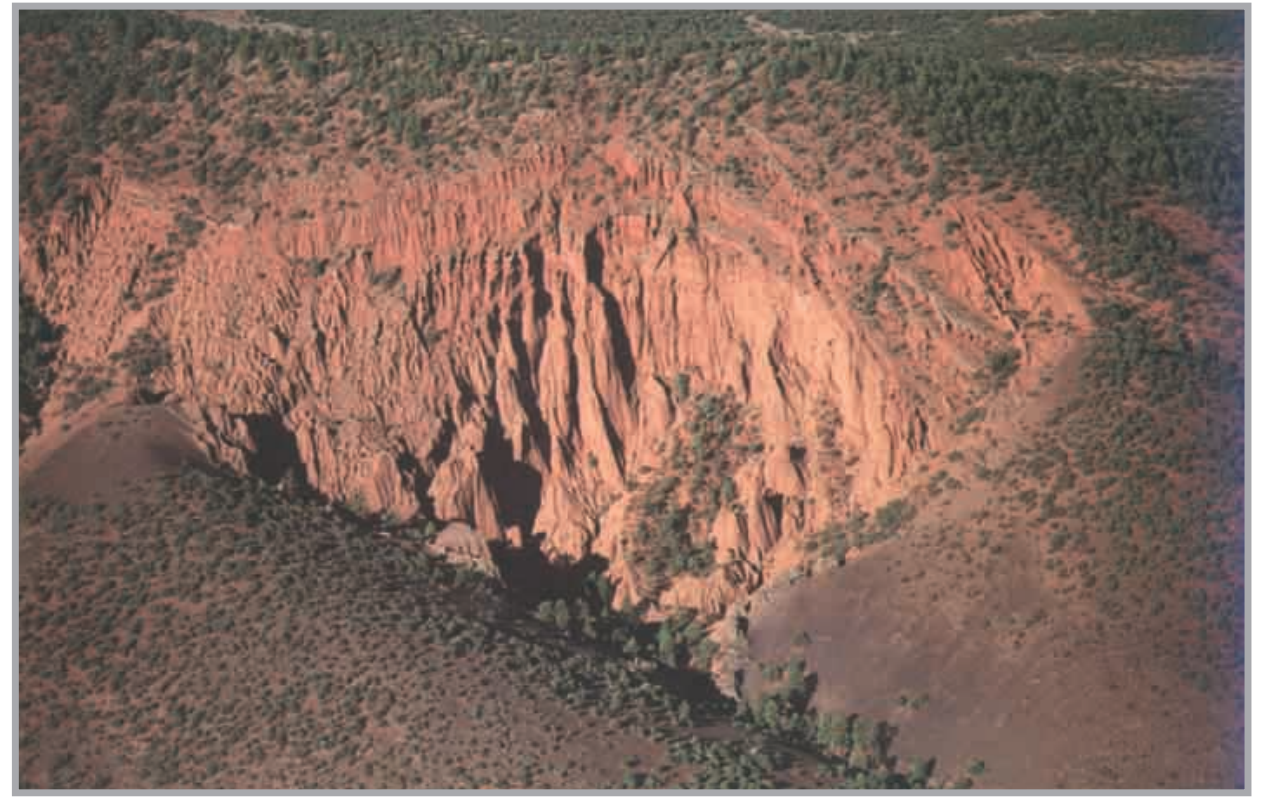

This aerial view of Red Mountain cinder cone in northern Arizona shows the deeply sculpted northeast flank of the volcano. The deep depression in the center of the image is a natural amphitheater, whose origin has been something of a geologic mystery. The back wall of the amphitheater is a nearly vertical 800-foot cliff, which tapers off to the right and left. The dipping layers of volcanic cinders that make up the cone can be seen in the walls of the amphitheater. The center of the volcano, the site of the vent where molten rock (magma) was erupted, is on the far side of the ridge. (Copyrighted photo courtesy of Michael Collier.)

not had enough time to expose their internal features. Although human quarrying creates frequently changing glimpses into a few of the cones in the volcanic field, quarries generally are unsafe for tourists and public access commonly is denied.

Near Red Mountain a large Forest Service sign along Highway 180 invites the motorist to exit and visit this cinder cone. A parking lot is located about a quarter mile off the highway. A gentle, uphill, 30-minute walk from the parking lot brings the visitor into a natural amphitheater carved into the northeast flank of Red Mountain. The back wall of the amphitheater is a nearly vertical 800-foot cliff, which tapers off to the right and left. Truncated layers of volcanic cinders form ledges and color bands across the amphitheater walls.
A visitor standing in the center of the amphitheater, nearly surrounded by towering cliffs of cinders, might think that this is the center of the volcano, the location of the vent where molten rock (magma) was erupted. However, the actual center of eruption was over the back wall of the amphitheater, out of sight. The amphitheater is a geologic feature that formed after the eruption ended and continues to be enlarged by erosion today.

\section{An "Ideal" Cinder Cone}

An "ideal" cinder cone forms when eruption occurs on flat ground. From deep within the Earth, magma charged with gas (like a carbonated drink) rises through a vertical pipe-shaped conduit and erupts as 

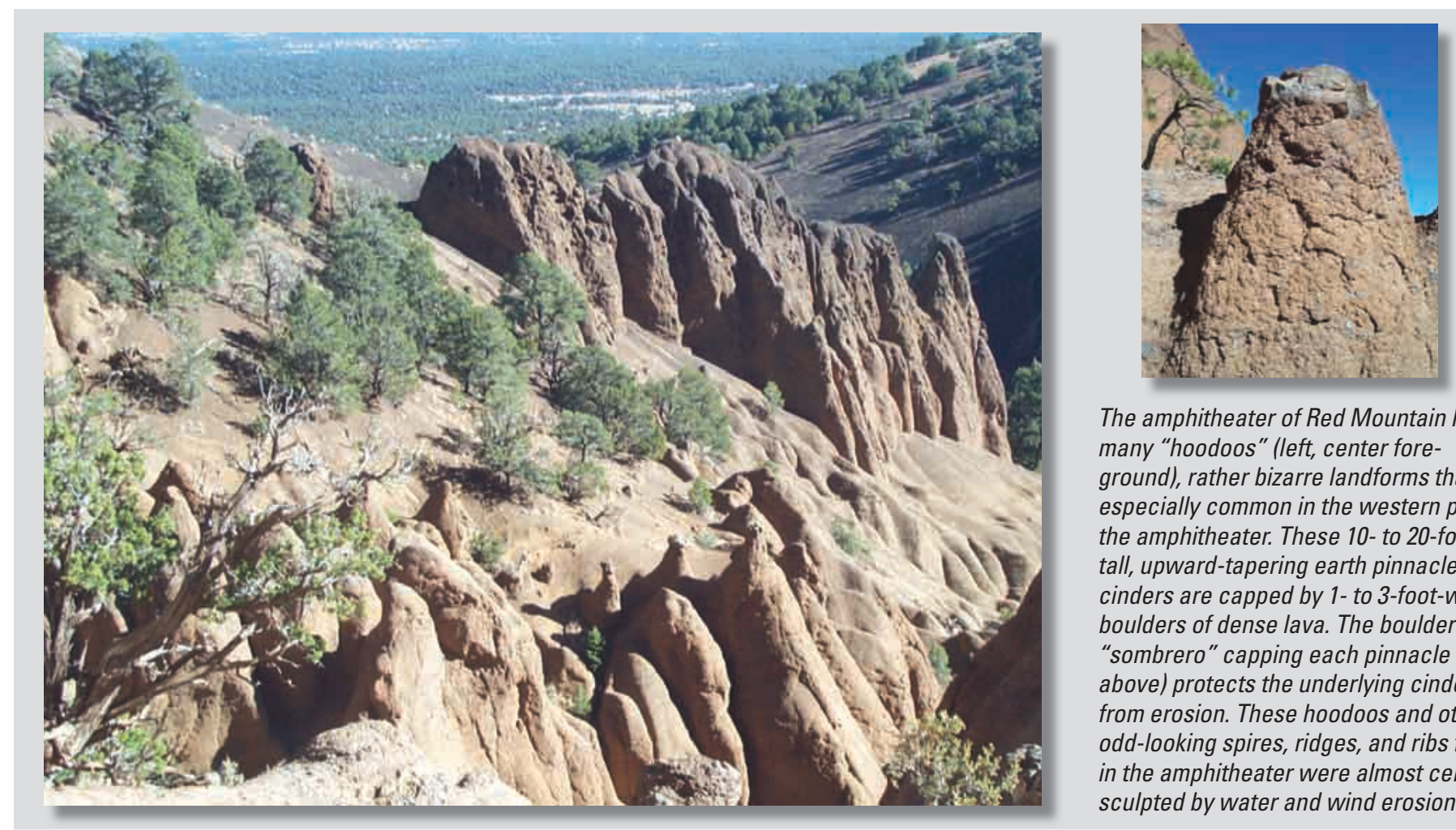

The amphitheater of Red Mountain has many "hoodoos" (left, center foreground), rather bizarre landforms that are especially common in the western part of the amphitheater. These 10- to 20-foottall, upward-tapering earth pinnacles of cinders are capped by 1- to 3-foot-wide boulders of dense lava. The boulder "sombrero" capping each pinnacle (see above) protects the underlying cinders from erosion. These hoodoos and other odd-looking spires, ridges, and ribs found in the amphitheater were almost certainly sculpted by water and wind erosion.

a fountain of frothy lava that may spray as high as 2,000 feet into the air.

As an individual blob of this frothy molten rock flies through the air, it cools quickly enough to solidify before falling

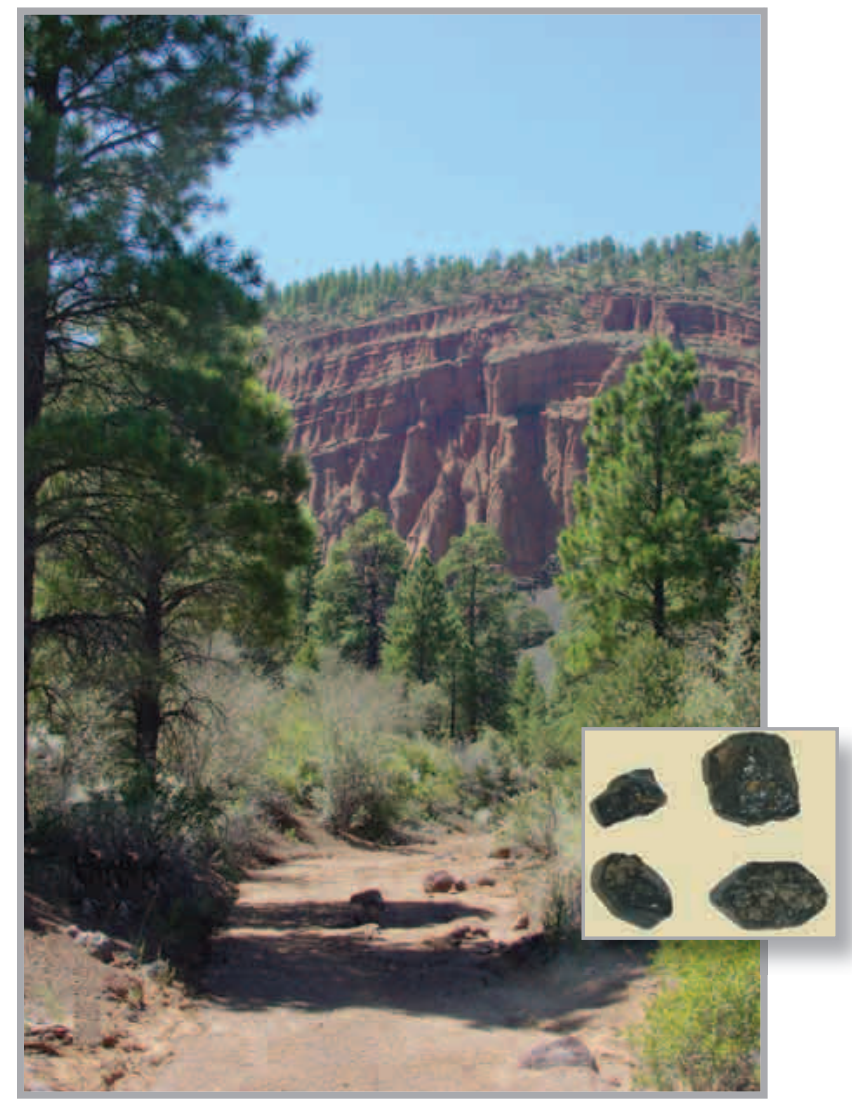

back to Earth. Many gas bubbles remain trapped in the fragments. If small, these fragments of rock are called "cinders," and if larger, "bombs." As eruption continues, cinders accumulate to form a conical hill.
Periodically, the flanks of the growing hill may become so steep that lobes and sheets of cinders slide downward. When lava fountaining ends, a symmetrical cone-shaped hill, commonly indented by a summit crater, has been added to the landscape. Internally, the cone is a pile of loose cinders in layers that dip away from the volcano's vent in all directions.

During the waning stage of an ideal cinder-cone eruption, the magma has lost most of its gas content. This gas-depleted magma does not fountain but oozes quietly into the crater or beneath the base of the cone as lava. Because it contains so few gas bubbles, the molten lava is denser than the bubble-rich cinders. Thus, it burrows out along the bottom of the cinder cone, lifting the less-dense cinders like a cork on water, and advances outward, creating a lava flow around the cone's base. When the eruption ends, a symmetrical cone of cinders sits at the center of a surrounding pad of lava.

\section{Red Mountain Cinder Cone}

Field studies conducted by U.S. Geological Survey (USGS) and Northern Arizona University scientists suggest that Red Mountain grew on a nearly flat surface that may have sloped gently to the north. However, little else about this volcano mimics the features of an ideal cinder 


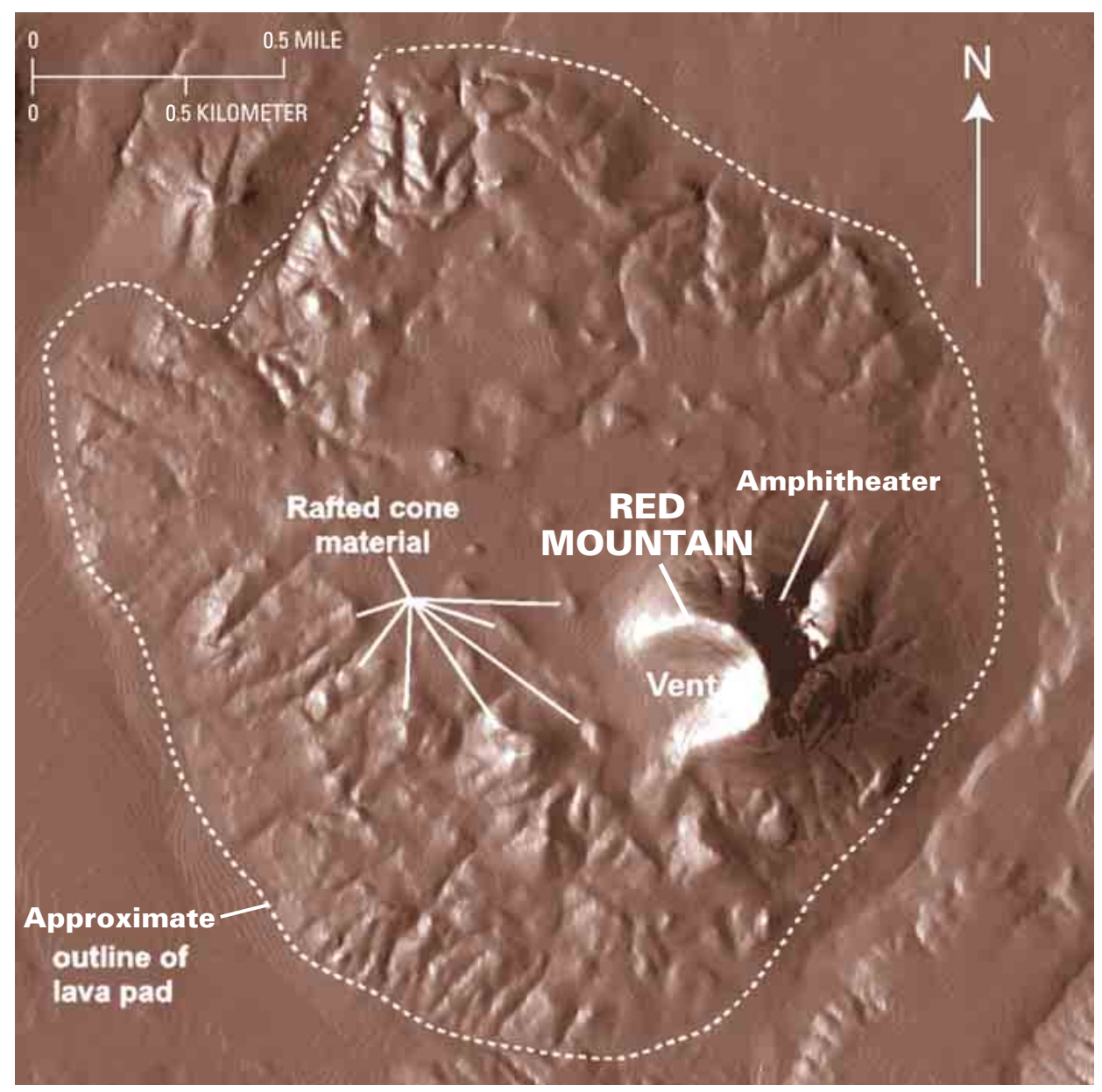

This digital elevation model (DEM) of the Red Mountain area shows the features of the cinder cone. During the eruption that formed it, Red Mountain grew on a nearly flat surface, which was eventually covered by a lava flow that extruded from the base of the cone during the eruption's waning phase. This lava flow rafted away some of the volcanic cinders that formed the western side of the cone. When viewed from above, Red Mountain today is a U-shaped landform open to the west, rather than a symmetrical "ideal" cinder cone, with a large natural amphitheater carved into its northeast flank. U.S. Geological Survey and Northern Arizona University scientists think that the amphitheater may have been blasted out by one or more steam explosions shortly after eruption ceased at the volcano's vent 740,000 years ago.

cone. When viewed from above, Red Mountain is a U-shaped landform open to the west, rather than a symmetrical cone. The base of the $\mathrm{U}$ is a curving ridge that forms the highest part of the mountain. The nearly half-mile-long arms of the $\mathrm{U}$ slope down to the west and merge with the gently rolling surface of the Red Mountain lava flow.

By carefully measuring the orientation of cinder layers over all parts of Red Mountain, geologists have mapped a radial pattern of layers, dipping away from the middle of the $\mathrm{U}$ in all directions. At the amphitheater, all the exposed layers dip uniformly to the northeast. This pattern indicates that the vent is somewhere in the middle of the $U$ and not at the amphitheater.
The shape of Red Mountain and its overall pattern of cinder layers raises the question of why a symmetrical cone was not created around the vent at the center of the U. Three possible explanations are:

- If the lava-fountaining phase of eruption occurred during a time of sustained wind blowing from west to east, most cinders could have been blown eastward creating the asymmetrical shape of Red Mountain. However, eruptions of the type that built Red Mountain usually last several years to a decade or longer, and it seems unlikely that a westerly wind could have persisted for such a period of time.

- Perhaps the conduit through which magma rose to the surface was inclined eastward enough to give the same effect as a westerly wind, but this seems unlikely because the driving force for rising magma is the buoyancy of very hot volcanic gases. Like a cork released in water, such gases tend to rise vertically rather than follow an inclined path.

- The most likely possibility is that the waning-stage lava flow of the Red Mountain eruption rafted the western section of the cinder cone away, like wood on flowing water. When gas-poor molten lava burrows its way outward beneath a cinder cone, it may either leave the cone undisturbed or carry pieces piggyback, literally floating pieces on the surface of the denser lava. Many examples of both situations are known worldwide; a spectacular example of rafting is found at Sunset Crater National Monument, northeast of Flagstaff. At Red Mountain, geologists have discovered several outcrops of layered cinder deposits, some of which are hundreds of feet wide and tens of feet thick, at the top of the lava flow. Typically, these "floaters" form hills on the surface of an otherwise fairly flat flow. Apparently, molten lava oozed out beneath the west base of Red Mountain and rafted away much of that side of the cinder cone, creating its $\mathrm{U}$ shape.

\section{Origin of the Amphitheater}

The origin of the Red Mountain amphitheater is something of a geologic mystery. The truncated cinder layers exposed in the amphitheater walls are clear evidence that material has been removed. However, how this removal was accomplished is not entirely clear.

It seems unlikely that the entire amphitheater was created by water erosion, because there is so little surface area to catch rainwater and snowmelt and funnel it down channels to erode the side of the volcano. An intriguing, though speculative, possibility is that one or more steam explosions created an amphitheater-shaped hole in the side of Red Mountain shortly after eruption ceased. Newly erupted cinders probably cooled to about $600^{\circ} \mathrm{F}$ as they fell back to earth, but then remained well above the boiling temperature of water for some time. Rainwater seeping into the 


\section{GETTING TO RED MOUNTAIN}

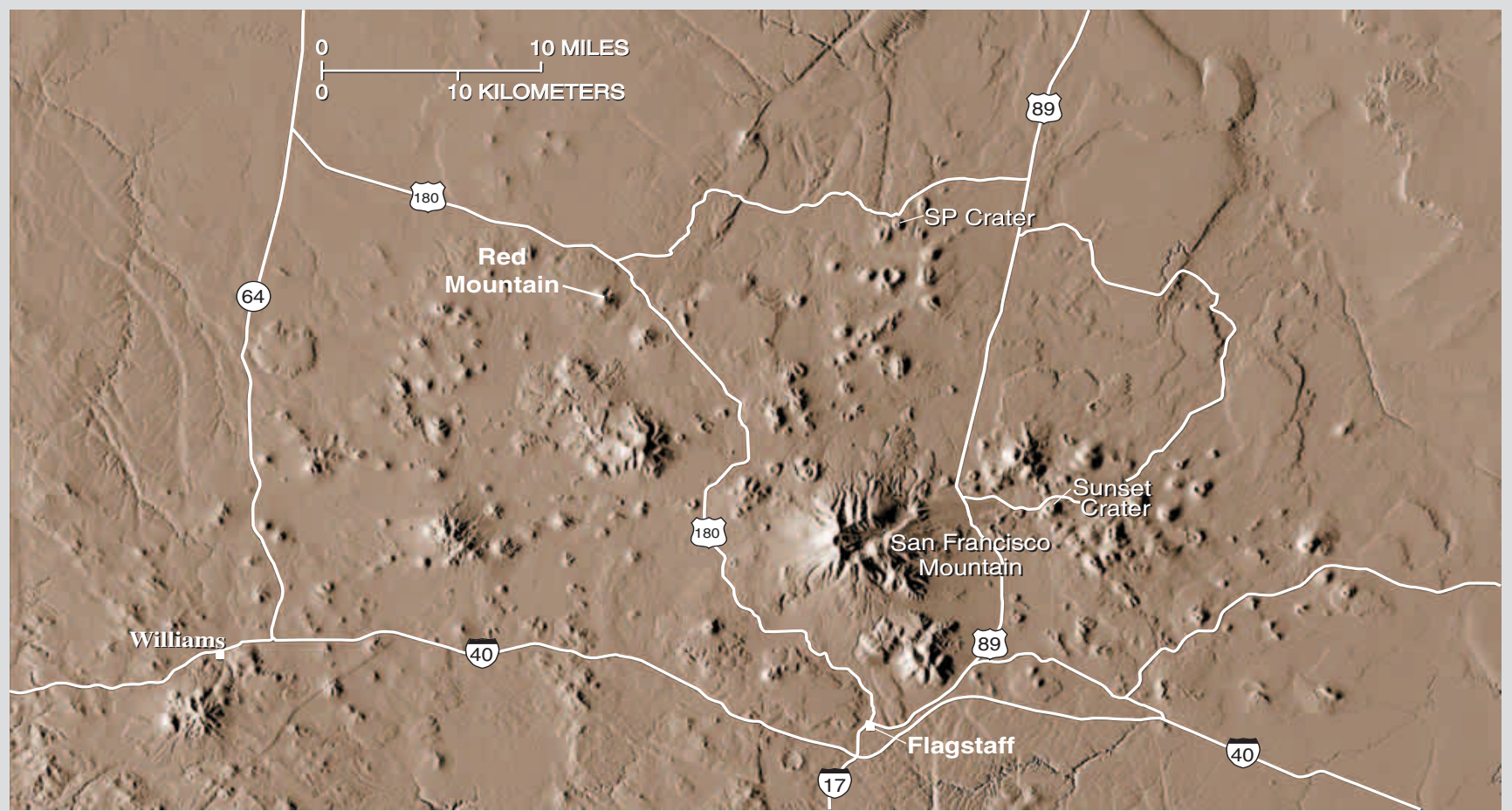

To reach Red Mountain from Flagstaff, head northwest on Highway 180. This highway snakes through the central part of the San Francisco Volcanic Field on its way toward the Grand Canyon. About 25 miles from Flagstaff (at milepost 247 along the shoulder of the highway), turn left at a large Forest Service sign that announces the Red Mountain Geologic Area. Drive about a quarter mile on the dirt road to a parking space at the trailhead. The walk from there to the base of Red Mountain takes about 30 minutes. Carry plenty of drinking water on a hot day (at least 1 liter of water per person). Trees in the natural amphitheater provide some shade.

cone and circulating through the still hot cinders may have quickly deposited a strong mineral cement that bound cinders together, creating the equivalent of a sealed "pressure cooker." Eventually, the pressure of the trapped superheated water may have exceeded the strength of that cooker, resulting in one or more steam explosions.

Two characteristics of the cinder layers seen in the amphitheater support this scenario. Although most cinder-cone volcanoes are piles of loose cinders, the cinders exposed in the walls of the amphitheater are partly cemented into hard outcrops by a mineral cement. Also, the cinders range in color from nearly black to reddish and brownish tints, indicating contact and chemical interactions with hot water and steam.

Even if a steam-blast scenario is correct, the initial amphitheater opening has been enlarged by normal surface-water and wind erosion during the approximately 740,000 years since it formed. For example, here and there, especially in the western part of the amphitheater, 10- to 20-foot-tall, upward-tapering pinnacles of cinders are capped by 1 - to 3-foot-wide boulders of dense lava. The boulder "sombrero" capping each pinnacle protects the underlying cinders from erosion. Geologists call this rather bizarre type of landform an earth pinnacle or "hoodoo." Much of the amphitheater is decorated with hoodoos and other odd-looking spires, ridges, and ribs, all of which were almost certainly sculpted by water and wind erosion.

The work of USGS and Northern Arizona University scientists, in cooperation with the U.S. Forest Service, has led to a better understanding of the geologic history of Red Mountain and the San Francisco Volcanic Field. This work is only part of the USGS Volcano Hazards Program's ongoing efforts to protect people's lives and property in all of the volcanic regions of the United States, including Wyoming, eastern California, the Pacific Northwest, Hawaii, and Alaska.

Susan S. Priest, Wendell A. Duffield, Nancy R. Riggs, Brian Poturalski, and Karen Malis-Clark

Edited by James W. Hendley II and Peter H. Stauffer

Graphic design by Steven L. Scott Banner design by Bobbie Myers

\section{COOPERATING ORGANIZATIONS}

U.S. Department of Agriculture, Forest Service Northern Arizona University

For more information contact:

U.S. Geological Survey 2255 N. Gemini Dr.

Flagstaff, AZ 86001 (928) 556-7148

http://volcanoes.usgs.gov/

or

U.S. Forest Service Coconino National Forest,

Peaks Ranger District

5075 N. Highway 89

Flagstaff, AZ 86004 (928) 526-0866

http://www.fs.fed.us/r3/coconino/

See also The San Francisco Volcanic Field, Arizona (USGS Fact Sheet 017-01), What are Volcano Hazards? (USGS Fact Sheet 002-97), Volcanoes (USGS General Interest Publication 94-0195), and Volcanoes of Northern Arizona by Wendell Duffield (Grand Canyon Association, 1997).

This Fact Sheet and any updates to it are available on line at http://geopubs.wr.usgs.gov/fact-sheet/fs024-02/ 